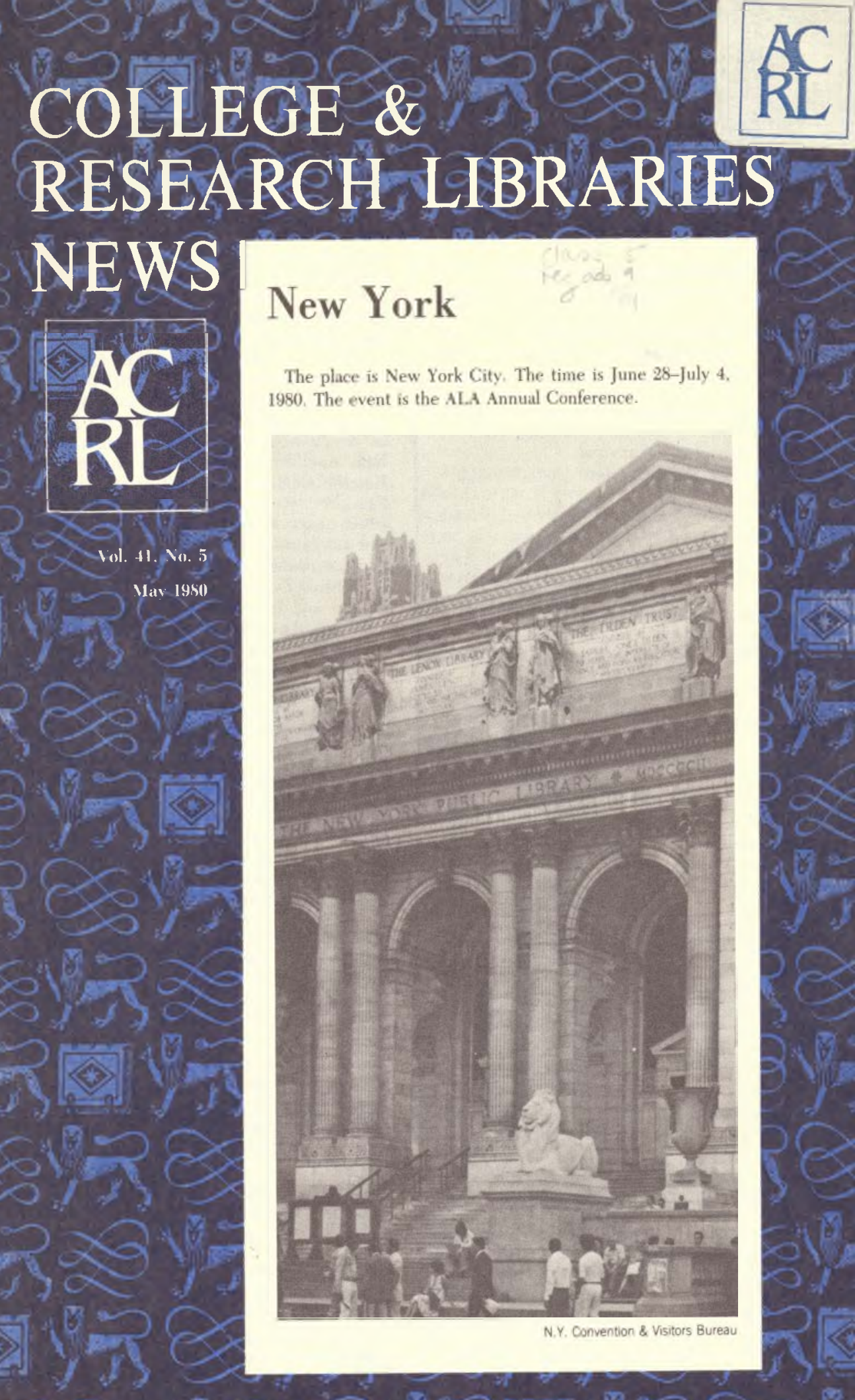


In this issue:

New York

Tentative Schedule of ACRL Conference Meetings

ACRL Members Run for

ALA Council as

Petition Candidates

College Library Section

Professional Survival:

The Job Interview

Continuing Education:

Career Goals-

Achieved through

Continuing Education .......140

News from the Field ........142

People ............... 143

Publications ...........151

Calendar .............. 153

Classified Advertising .......155

College \& Research Libraries News is published by the As. sociation of College and Research Libraries, a division of the American Library Association, as 11 monthly (combining July-August) issues, at $50 \mathrm{E}$. Huron St. Chicago, IL 60611 . Annual subscription: $\$ 5$; or to members of the division, $\$ 2.50$ included in dues. Single copies and back issues, $\$ 2$ each. Second-class postage applied for at Chicago, llinois, and at additional mailing offices (ISSN 0099-0086).

Editor: Jeffrey T. Schwedes, ACRL/ALA, $50 \mathrm{E}$. Huron St. Chicago, IL 60611; (312) 944-6780. Ext. 286. President ACRL: Le Moyne W. Anderson. Executive Secretary. ACRL: Julie A. Carroll Virgo.

Production and circulation office: $50 \mathrm{E}$. Huron St., Chicago, It 60611. Display advertising should be sent to Leona Swiech, Advertising Traffic Coordinator. ALA at above address. Send classified ads to ACRL. Change of address and subscription orders should be addressed to College \& Research Libraries News, for receipt at the above address at least two months be. fore the publication date of the effective issue,

Inclusion of an article or advertisement in C\&RL News does not constitute official endorsement by ACRL or ALA.

A partial list of the services indexing or abstracting the con tents of C\&RL News includes: Current Contents: Social \& Behavioral Sciences; Current Index to Journals in Education; Information Science Abstracts: Library \& Information Science Abstracts; Library Literature, and Social Sciences Citation In dex.

(C)American Library Association 1980. All material in this journal subject to copyright by the American Library Association may be photocopied for the noncommercial purpose of scientific or educational advancement.

\section{ACRL IN NEW YORK}

ACRL's New York program schedule is packed with activities. Special events include a reception at the Columbia University Library, a behindthe-scenes visit to the American Museum of Natural History, and a tour of Long Island community colleges. ACRL will offer programs on topics ranging from scholarly communication to international government documents.

Scan the ACRL schedule for the programs, meetings, and activities that interest you, and make plans to meet us in New York.

ACRL Program Meeting: "Scholarly Communication: The Report of the Nationa! Enquiry-A Critique" (July 1, 3:00-5:30 p.m.) will be the theme of the ACRL Program Meeting in New York. Participating in the program will be Hendrik Edelman, university librarian, Rutgers University; George Winchester Stone, president, International Federation for Modern Languages and Literatures; Beverly P. Lynch, university librarian, University of Illinois at Chicago Circle; J. Edwards Evans, professor, Graduate School of Library and Information Science, University of California, Los Angeles; and Herbert S. Bailey, Jr., director, Princeton University Press."

An ACRL Membership Meeting (July 1, 2:003:00) will be held just prior to the ACRL Program Meeting to give members a chance to question ACRL officers and to discuss the affairs of the Association.

The ACRL Reception (July 1, 6:00-8:00), sponsored by the Baker \& Taylor Company, will take place at the Columbia University Libraries immediately after the ACRL program meeting. At the reception the Academic or Research Librarian of the Year Award will be presented by ACRL and the Baker \& Taylor Company.

Academic Status Committee: "The Role of the Academic Librarian" (July 1, 9:00 a.m.-11:00 a.m.) is the topic of the program that will be offered by the Academic Status Committee. The program will consist of presentations by a college teacher, a researcher, and an administrator on the role of the academic librarian in teaching and research. A reactor panel of three librarians will respond to the remarks of the principal speakers. After the presentations and responses, the meeting will be thrown open for questions and answers.

The speakers will be Mario DiCesare, professor of English and Comparative Literature at the State University of New York at Binghamton; Donald McNemar, associate professor of government and associate dean of the faculty for social sciences at Dartmouth College; and Norman Mintz, acting provost of Columbia University. The three librarians on the reactor panel will be Irma Johnson, science librarian, Massachusetts Institute of Technology; Margaret Groesbeck, in- 
structional services/reference librarian, Amherst College; and another librarian to be announced.

Audiovisual Committee and College LibraRIES SECTION: "The Marriage/Divorce of Print/ Nonprint: Some Thoughts on Merging Library and Media Services" (July 1, 9:30 a.m.-12:30 p.m.) will be the subject of a panel program offered by the College Libraries Section and the Audiovisual Committee. Four speakers will explore the issues and practical problems raised by the merger of print and nonprint collections and services in academic libraries. Jay Poole, editor of Choice, will discuss collection development issues; Dwight Burlingame, dean of Libraries, Bowling Green University, will approach the topic from an administrative point of view; Mel Smegerinski, director of the Educational Communications Center, State University College at Brockport, New York, will speak as a nonlibrarian who does not recommend such mergers; and a practicing media librarian will discuss practical service problems likely to be encountered by those carrying out such a merger.

Continuing Education Committee: "The Academic Library Management Intern Program of the Council on Library Resources: Views from Inside" (July 2, 2:00-4:00 p.m.) will be the subject of a panel discussion presented jointly by the Continuing Education Committee and the LAMA Personnel Administration Section.

The panel will consist of the director of a host library, Rutherford D. Rogers of Yale University, and two participants, Barbara J. Brown, assistant librarian for General Reader Services at Princeton, and Sara C. Heitshu, head of the Serials Division at the University of Michigan. The discussion will give the profession direct information for the first time about what happens during the year-long internship experience and about the program's impact on participants and host institutions. A question-and-answer period will follow the panel discussion. All former and present interns and host directors have been invited to attend.

Copyright Committee; "Copyright: The Rights of Creators and the Interests of Users" (July 1, 9:30-11:00 a.m.) is the title of a joint program to be offered by the ACRL Committee on Copyright (Ad Hoc) and the ALA Legislation Committee Copyright Subcommittee (Ad Hoc). The purpose of the program is to provide a forum for the presentation of various viewpoints on copyright issues. Barbara Ringer, a former Register of Copyrights, will speak on "Copyright and the Public Interest: Promoting the Progress of Science and the Useful Arts." Ivan R. Bender, vice-president and general counsel, FILMS, Inc., and Elwood K. Gannett, director of Publishing Services, Institute of Electrical \& Electronic En- gineers, will speak on "Copyright and the Private Interest: The Impact of Technology on Copyrights."

Librarians of Library Science Collections Discussion Group: A "Tour of the H. W. Wilson Company" (July 1, 9:30-11:00 a.m.) will be sponsored by the Librarians of Library Science Collections Discussion Group. The tour of the headquarters of this major library publishing company will focus especially on the production of Library Literature and other major indexes and books. Transportation will not be provided, but directions will be available at the Tour Information Desk. Those interested should notify Dr. Eva L. Kiewitt, Graduate Library School, Indiana University, Bloomington, IN 47405, by June 1 .

anthropology and Sociology Section: "For Studying the Human Condition: The HRAF Information System" (July 1, 9:30-11:00 a.m.) is the topic of a presentation on the Human Relations Area Files that Robert $O$. Lagacé will give at the program meeting of the Anthropology and Sociology Section. Lagacé is vice-president and executive director of the Human Relations Area Files, New Haven, Connecticut. The presentation will focus on selection criteria for source documents, the organization of the collection, and its strengths and weaknesses.

"American Museum of Natural History Tour: Behind-the-scenes Highlights" (July 2, 2:30-5:30 p.m.) will feature a preview of the Hall of Asian Peoples (scheduled to open in October), visits to storage facilities of the Anthropology Department, and a tour of the Museum Library. The tour will give participants an opportunity to meet museum staff and to learn about new techniques of collection management and exhibition now in use at the museum.

Attendance will be limited to the first ninety applicants. The registration deadline is June 13. To apply send a tax-deductible contribution of $\$ 5$ (made out to American Museum of Natural History) to Patricia W. Silvernail, Columbia University Libraries, 535 West 114th Street, New York, NY 10027.

Art Section: "Exploring the Art Market: Some Information Sources" (June 30, 9:30-11:00 a.m.) is the title of the program to be offered by the Art Section. Entering the art marketplace can be a bewildering experience for the buyer, seller, exhibitor, or scholar. The best way to make wise purchases in the field of art is to know what you are buying. The Art Section program will explore the resources that contain information pertaining to the value of art objects. Topics will include art law, determining authenticity, auction records, investments, sales catalogs, and price guides.

Asian and African Section: "China Report" (June 29, 2:00-5:30 p.m.), a joint program of the 
Asian and African Section and the International Relations Roundtable, will feature a presentation by three librarians who participated in the American Library Delegation Study Trip to the People's Republic of China in September 1979. Peggy Sullivan, Russell Shank, and Alice Ihrig will join forces to show slides and talk about their experiences in the People's Republic.

Bibliographic Instruction Section: "Learning Theory in Action: Applications in Bibliographic Instruction" (July 1, 9:30 a.m.-12:30 p.m.) is the theme of a program that will be sponsored jointly by the Bibliographical Instruction Section and the Community and Junior College Library Section's Instruction and Use Committee. The two speakers featured wil] discuss the relevance of learning theory to bibliographic instruction and describe the instruction programs at their own institutions. Sharon J. Rogers, coordinator, Library Programs, University of Toledo Libraries, will give a talk entitled "Theoretical Designs: Issues, Questions, Procedures." Cerise Oberman-Soroka, head of the Reference Department, College of Charleston, North Carolina, will speak on "Petals around a Rose: Abstract Reasoning and Bibliographic Instruction." After the formal presentations, there will be a workshop for those interested in gaining hands-on experience in applying learning theory to library instruction planning,

BIS Committee on CoOpenation: “Approaches to Encouraging Library Use Instruction in Professional Associations for Subject Disciplines" June 29, 4:30-5:30 p.m.) will be the topic of a discussion session sponsored by the Committee on Cooperation of the Bibliographic Instruction Section. The session will provide a forum for sharing ideas about ways of promoting library use instruction among associations like the American Chemical Association or the American Historical Association.

Bis Continuing Education Committee: "Present and Future Needs in Bibliographic Instruction" (June 30, 2:00-5:30 p.m.) will be the subject of an informal discussion sponsored by the BIS Continuing Education Committee. The discussion will help to guide the future work of the committee. Suggestions of topics to be explored at the meeting are welcomed. Send questions or ideas to Joan Ormondroyd, Cornell University, Ithaca, NY 14853, or Kay Rottsolk, St. Olaf College Library, Northfield, MN 55057.

College Library Section: See Audiovisual Committee.

Community and Junior College Libraries Section: "Services to the Disadvantaged in Community Colleges" (June 29, 9:30 a.m.-4:00 p.m.) is the title of CJCLS's New York Program. Kay M. Stansbery, coordinator of Technical Proces- sing Services, Tarrant County Junior College District, will introduce the morning program with a presentation on "Meeting the Needs of the Physically Handicapped Student." Next a panel of librarians will discuss what community college libraries have actually done to meet the needs of physically handicapped students. The panel will consist of Susan Miller Maltese (moderator), Oakton Community College, Morton Grove, Illinois; James F. McCoy, Hudson Valley Community College, Troy, New York; and other panelists to be named.

At the program luncheon, Byron N. McClenney will speak on "Meeting Learning Resources Needs as Viewed by a Community College President." McClenney is president of Parkersburg Community College, Parkersburg, West Virginia.

In the afternoon the section will have its business meeting and then break up into groups to discuss various aspects of community college librarianship. One of the discussion groups will focus on the issue of participation by community college librarians in ALA.

The section will also sponsor a tour of Long Island Community Colleges (June 30, 9:00 a.m.4:00 p.m.).

EBSS Psychology/Psychiatry Committee (AD HOC): "Psych Abstracts: Inside and Out" (June 29, 2:00-4:00 p.m.) will be the title of a program sponsored by the EBSS Psychology/Psychiatry Committee. The aim of the program will be to review the purposes and structure of Psychological Abstracts and to assess how well it is serving the needs of its users. Greg Payne, director of User Services, PsychInfo, Inc., Washington D.C., will deliver a talk on Psychological $A b$ stracts; a panel discussion will follow. The panelists will be Thelma Freides, State University of New York College at Purchase; Charlotte Doyle, Sarah Lawrence College; and Terence Hines, Cornell University Medical College.

“Academic Psychology/Education Test Collections: A Working Session" (June 30, 2:00-4:00 p.m.) will seek to define the problems of psychological and educational test collections and to determine whether there is a need to develop guidelines for such collections. The meeting will begin as a structured discussion and then will break up into informal discussion groups. Representatives of the Educational Testing Service and the ERIC Clearinghouse on Tests, Measurement, and Evaluation will participate in the discussion.

Law and Political Science Section: "State Publications: Acquisition, Control, and Service" (June 29, 8:00-10:00 p.m.) is the subject of a joint program of the Law and Political Science Section and the ALA Government Documents Roundtable. The speakers and their topics will be: Agnes Ferruso, Library of Congress-"How the Checklist of State Publications Comes into Being at the Library of Congress"; Margaret Lane, 
Baton Rouge, Louisiana-"Sources of Information Regarding State Publications and Legislative Documents"; Nancy Johnson, University of Illinois Law Library-"Providing Service with State Publications"; and Ron Haselhuhn, School of Library Science, Emporia State University, Kansas"Results of a Survey on Use of State Publications."

Rare Books and Manuscripts Section: "Machine-Assisted Processing of Special Collections" (June 29, 2:00-4:00 p.m.) will be the subject of a Rare Books and Manuscripts Section panel discussion. One of the panelists will speak on the background and current status of rare book cataloging standards for the MARC format developed by the Independent Research Libraries Association Rare Book Committee and now under review by the ACRL RBMS Standards Committee. The panel will also include a librarian responsible for processing with OCLC; a librarian responsible for processing with RLIN; and OCLC and RLIN representatives who will discuss current and future network capabilities with respect to processing special collections.

Science and Technology Section: "Problems of Librarians Serving Users in Science and Technology Areas" (June 29, 9:30 a.m.-12:30 p.m.) is the theme of the Science and Technology Section Program meeting. The program will begin with a keynote address by Allen $\mathrm{S}$. Lefohn, chair of the Western Information Network on Energy, Helena, Montana. Lefohn will speak on "Creativity-Should We Use It?" After the address (and a question and answer period), the meeting will divide into four panels meeting simultaneously. The panels will tackle the following topics: (1) Outreach-Getting Information to the User; (2) Systems Available for Delivery of Information; (3) Machine-readable Bibliographies; and (4) Collection Development. The panel leaders will report the results of the group discussions at the conclusion of the program.

Slavic and East European Section: Slavic studies and Slavic bibliography will be the featured topics at the Slavic and Eastern European Section program meetings. At the program luncheon (June 29) Dean Thomas E. Bird of the City University of New York, a noted scholar and lecturer, will speak on the history of Slavic studies in the United States. Another portion of the program will present a roundtable discussion on "Teaching Slavic Bibliography in the United States." And as an added feature, it will be possible to visit on an open-house basis more than a half-dozen bookstores and specialized libraries in New York. The section is also preparing an information booklet on Slavic New York.

University Libraries Section: "The Rising Cost of Serials: Practical Methods of Coping"
(June $30,2: 00-5: 00$ p.m.) will be the subject of a program sponsored jointly by the ACRL University Libraries Section, the RTSD Reproduction of Library Materials Section, the RTSD Resources Section, and the RTSD Serials Section. The program will be moderated by Richard Boss of Information Systems Consultants, Inc. Speakers will be Hendrik Edelman of Rutgers University Libraries, Lee Jones of the Council on Library Resources, and Vincent Gujliano of Arthur D. Little, Inc. There will be time for questions from the audience at the end of the program. A handout on library materials, price indexes, and a bibliography on serials will be available.

Westenn European Speclajists Section: "The Government Documents of Western Europe" (June $29,9: 30$ a.m. $-12: 30$ p.m.) will be the subject of a program offered by the Western European Specialists Section in cosponsorship with the GODORT International Documents Task Force. Three speakers will provide an overview of what is published, what the means of bibliographic access are, what libraries should be collecting, and the whys and wherefores. The speakers and their topics are: Eve Johansson, Official Publications Library, The British Library, "The Organization of Government Publishing in Western Europe"; Gloria Westfall, Indiana University Libraries, "Access to French Official Publishing"; David Rozkuszka, Stanford University Libraries, "Foreign Official Publications: Domesticating the Unknown." The program will conclude with a panel discussion on acquisitions, collection policy statements, retrospective collection development, automation, resource sharing, and micropublishing as they relate to the official publications of Western Europe and to the archive and document collections of the panelists' own libraries. The four panelists are: Anthony Angiletta, Yale University Library; James Campbell, University of Virginia Library; Joan Higbee, Library of Congress; David Rozkuszka, Stanford University Libraries.

\section{Volunteers Needed}

Librarians are needed to help staff the Exhibits Round Table at the ALA New York Conference this summer. An exhibitor will be working with each volunteer. Exhibit hours will be: Saturday, June $28,9: 00$ a.m. $-5: 00$ p.m.; Sunday, June 29, 9:00 a.m. $-4: 00$ p.m.; Monday, June 30, 9:00 a.m.-5:00 p.m.; and Tuesday, July 1, 9:00 a.m.-3:00 p.m. Send your name and the hours you can assist (preferably a two-hour block) by June 20 to Margaret Stewart, Christopher Newport College Library, 50 Shoe Lane, Newport News, VA 23606. 